ACTA 1 HERIOLOGICA

Vol. 28, 4: 55-71, 1983

\title{
Energy Allocation in Response to Reduced Food Intake in Pregnant and Lactating Laboratory Mice
}

\author{
John E. HEASLEY
}

\begin{abstract}
Heasley J. E., 1983 : Energy allocation in response to reduced food intake in pregnant and lactating laboratory mice. Acta theriol., 28, 4: 55-71 [With 3 Tables \& 7 Figs.]

An empirical and modeling approach was taken to the study of the mechanisms of energy allocation in small mammals. Feeding trials were conducted to provide data on the relationship between body weight, body composition, milk production, and food intake in white laboratory mice (Mus musculus). Pregnant and lactating females were fed ad libitum and at five levels of reduced intake during gestation only, gestation and lactation, and lactation only. A simulation model for energy allocation in small mammals was developed from data and concepts from the literature and model experiments with data from the feeding trials. Model predictions of body weight changes were compared with observed data to test the hypothesis of the energy allocation model. Reduced intake resulted in female weight loss, lower birth weights, lower milk production, and increased cannibalism. Basal metabolism and activity were also reduced. Model body weight predictions met the test criterion for all of the 86 adult mice and $91 \%$ of the 53 litters observed. Energy available for gestation or lactation appears to be constant and is probably limited by the maximum rate of gluconeogenesis. The reduction in energy expenditures during reduced intake might be explained by the reduced rate of supply of fatty acids as fat stores become depleted.

[Natural Resource Ecology Laboratory, Colorado State University, Fort Collins, CO 80525, USA]
\end{abstract}

\section{INTRODUCTION}

Much attention has been given to the determination of mammal energy requirements for maintenance, normal production, and production under increased energy intake. Very little has been done relative to energetic relationships under reduced intake conditions. That which has been reported is of a qualitative nature. That is, results are reported as: decreased energy intake results in loss of body weight and fat (e.g., Lodge \& Heaney, 1973) ; energy stores are used during lactation (Randolph et al., 1977); or decreased protein intake by pregnant females results in lower birth weights and juvenile growth rates (Barnes et al., 1973). Relatively little has been reported quantitatively with respect to the mechanisms responsible for balancing energy expenditures with inputs during periods of reduced energy intake. Much of this is probably due to our inability to measure these mechanisms. The goal of this study 
was to quantitatively describe the allocation of energy in laboratory mice during periods of high energy demand (i.e., gestation and/or lactation) when food intake is reduced.

There is considerable evidence for the maintenance of equilibrium between input energy and energy expenditures in mammals (Baile \& Forbes, 1974 ; Bray \& Campfield, 1975). Increased energy losses resulting from low environmental temperatures, reproductive expenditures, or increased activity are generally offset by increases in the amount of energy taken in as food (Moose et al., 1969 ; Peterson \& Baumgardt, 1971). When energy losses cannot be balanced through increased intake because of physical or temporal limitations on the animal, the deficit must be made up through catabolism of energy stores or a reduction in the expenditure of energy. This is in accordance with the law of conservation of energy. It is this maintenance of energy equilibrium upon which the control of energy allocation in small mammals is based. Energy equilibrium is the state in which the flows of energy out of the labile pool (represented by blood metabolites such as blood glucose) to storage forms or heat are offset by the energy supplied from the consumption of food or catabolism of energy stores. The goal of the mechanisms for the allocation of energy is to maintain energy equilibrium. This is accomplished through regulation of food intake, catabolism of energy stores, or reduction in energy requirements.

When food is abundant, energy equilibrium is maintained through the regulation of food intake according to energy demand. As food becomes scarce control shifts to catabolism of energy stores. As the energy demand begins to exceed the supply, maintenance of energy equilibrium is achieved by reduction in energy requirements through curtailment of functions not essential to survival. Thus, an animal under energy stress will continue to supply energy to reproductive functions, although perhaps at a reduced rate. When the requirements of the reproductive function jeopardize survival, gestation or lactation is terminated. Energy available for gestation is a function of the difference between the total energy available (daily metabolizable energy intake plus catabolized energy) and maintenance requirements. If the maintenance requirements of the fetus and reproductive apparatus can be met, fetal development will continue, albeit at a reduced rate. As a result, the young born will be smaller in size and have less energy reserves. Mortality of such young should be comparatively high in relation to large young (Sinclair \& Crawford, 1973). Energy for lactation is allocated in a similar manner. In response to reduced intake, milk production would be reduced with detrimental effects on the young (Corah et al., 1975). 


\section{METHODS}

The approach used in this study included both empirical and modeling techniques. Empirical data were collected to provide information for model development and hypothesis testing. Simulation models were developed to integrate available information concerning energy allocation, in small mammals, to provide feedback for empirical investigation, and to serve as vehicles for hypothesis tests. The general procedure consisted of constructing models with information from the literature and, later, collecting empirical data for comparison. The data collected were then used to refine the models and to assess body weight variability. Information gained from the model exercise was then utilized in a second set of experiments. Data from these experiments were used to test the hypothesis represented by the energy allocation model.

\section{Empirical Methods}

White laboratory mice (Mus musculus) of the Rocky Mountain laboratory strain (Wildlife Disease Laboratory, Bear River Migratory Bird Refuge, Utah) were used because they are easy to work with and their physiology was well studied (Green, 1966). Two types of feeding trials were conducted: (1) to ascertain the efficiency with which mice assimilate Purina Lab Chow and (2) to provide data on the relationship between body weight, body composition, and food intake.

Twelve female mice were placed individually in metabolic cages, and feces and urine were collected for a six-day period. Daily food intake was also recorded. Ten samples of Purina Lab Chow were burned in a Parr oxygen bomb calorimeter to determine energy content. Urine and feces were dried in an oven at $100^{\circ} \mathrm{C}$ to a constant weight and also burned in the bomb calorimeter to determine energy content. Assimilation efficiency was defined as the ratio of gross energy intake less fecal and urinary energy to gross energy intake.

Two experiments were conducted to provide data on the relationship between food intake, body weight, and body composition in adult female mice during gestation and lactation. In the first experiment 40 pregnant mice were placed in individual cages. Each cage was equipped with a nest box and a feeder designed to reduced food wastage. Both food (Purina Lab Chow) and water were given ad libitum. Daily food intake was determined as the difference in weights of feeders plus food on consecutive daily weighings. Each day all food was removed from the cage for 4 hours. At the end of this 4-hour fast each mouse was weighed on a Mettler model P1200 balance to the nearest hundredth of a gram. Following parturition, litters were also weighed daily and the litter size determined. Missing young were assumed to have been eaten and recorded as an occurrence of cannibalism. All weight measurements were taken between 1200 and 1300 hours.

The date of parturition was recorded as day zero for lactation. Some individuals did not exhibit a vaginal plug as an indication of conception and were assumed to have a gestation period of 19 or 20 days, depending on the birth weight of the juveniles. Those with birth weights of less than 1.55 grams were assumed to be 20 days. The value of 1.55 grams is the median weight between a neonate having a 19-day gestation (1.38 grams) and a neonate having a 20-day gestation (1.72 grams).

Ambient temperature was recorded daily with a Henry J. Green (type 6685551-3188) hydrothermograph recorder. A single daily temperature was determined 
as that temperature that produced the equivalent thermoregulatory requirements of the hourly temperatures recorded when applied for a 24-hour period. This was calculated by first determining the total thermoregulatory requirement for the day by summing the requirements for each hourly temperature, using Kleiber's (1961) generalized equation for thermoregulation. The constant daily temperature was then determined (again using Kleiber's equation) as that temperature that, when applied for 24 hours, would produce the same total thermoregulatory requirement. During this experiment, females and their litters were randomly selected at 5-day intervals to be sacrificed for body composition determination.

In the second experiment, 60 pregnant mice were placed in individual cages. Energy intake was reduced to determine its effect on body weight and composition. The mice were divided into four groups:

(1) Those fed ad libitum.

(2) Those whose intake was reduced during gestation only.

(3) Those whose intake was reduced during gestation and lactation.

(4) Those whose intake was reduced during lactation only.

Twenty mice (five in each group) were fed $50,60,75$, and $90 \%$ ad libitum from the twelfth day of gestation through parturition, after which they were fed ad libitum. Fifteen mice (five in each group) were fed 60,75 , and $90 \%$ ad libitum from the twelfth day of gestation through the twentieth day of lactation. Eight mice were fed $40 \%$ ad libitum from the twelfth through the twentieth day of lactation. Four of these were returned to ad libitum on the eighteenth day to provide data on body weight recovery. The remaining 17 mice were fed ad libitum for the entire reproductive cycle. Those mice that failed to become pregnant were continued through the experiment as ad libitum nonpregnant individuals. A few of these mice refused to eat from the feeders and thus provided data on body weight changes during starvation and recovery. Recovery was achieved by hand feeding these mice.

Daily food intake, air temperature, and body weights were determined in the same manner as in the first experiments. Females and their litters were sacrificed on the twentieth day of lactation. Those individuals who ate all of their litter were sacrificed immediately after that event.

Mice were sacrificed by asphyxiation with nitrogen, their body cavities opened, and freeze dried. Live body weight was recorded before sacrifice. Following freeze drying, dry weight was recorded and the carcasses were cut up and placed in extraction thimbles for fat extraction. Except for very large ones, entire litters were fat-extracted in one thimble. Fat was removed from the carcasses through a soxhlet ether extraction process for a 20 -hour period. Lean dry and fat weights were recorded for each mouse and litter. Water content was determined by subtraction.

\section{Model Development}

The energy allocation model was developed around energy balance equations from the literature. This was augmented with the development of unknown mechanisms through model experiments using empirical data. Energy allocation is accomplished through the maintenance of the energy equilibrium equation:

$$
\text { Energy Flow In = Energy Flow Out. }
$$

Energy equilibrium is maintained through the control of a labile energy pool to a specified level. Labile energy represents both input energy (intake) and output energy (energy used). Input energy (observed gross energy intake) is converted 
to net energy intake and added to the labile energy pool. Maintenance requirements are calculated and then subtracted from the labile energy pool. If the individual is pregnant or lactating, excess energy in the labile pool plus some stored energy is made available for gestation or lactation. Reproductive energy requirements are then removed from the labile pool. If the pool level remains above the control level, excess energy is deposited as fat or protein. If the pool level falls below the control level, the deficit is mobilized from fat or protein to return

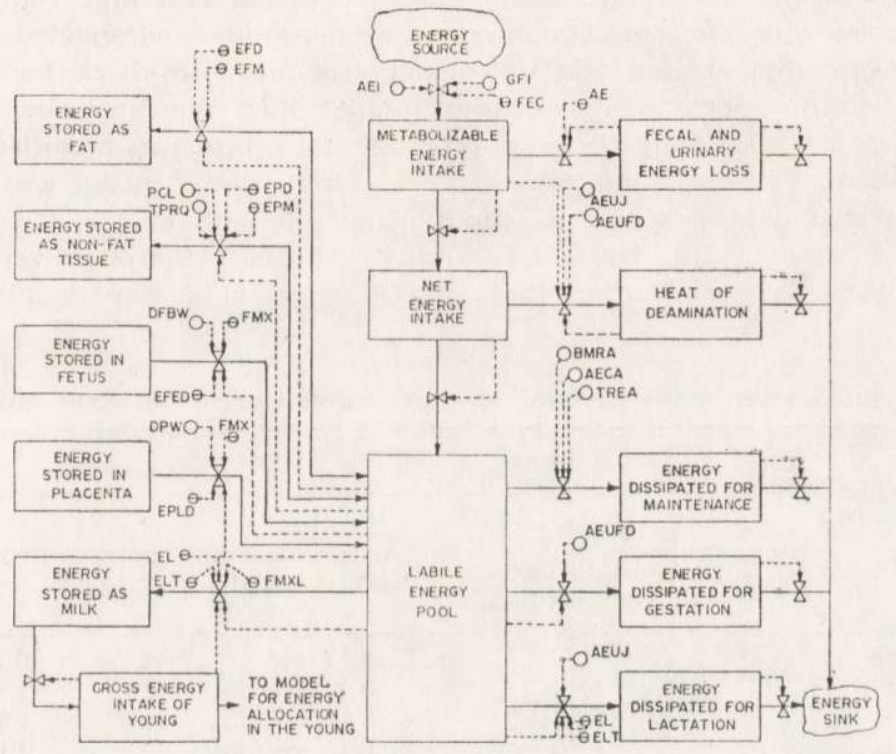

Fig. 1. Generalized Forrester diagram for the energy allocation model.

Key to terms in the model Forester diagram:

AE, Adult assimilation efficiency ;

AECA, Adult activity energy expenditure (kcal);

AEI, Adult energy intake through cannibalism;

AEUFD, Actual energy utilized for fetal development (kcal/day) ;

AEUJ, Actual energy utilized for lactation (kcal/day);

BMRA, Adult basal metabolic energy expenditure (kcal) ;

DFBW, Change in fetal body weight (gm);

DPW, Change in placental weight $(\mathrm{gm})$;

EFD, Efficiency of adult fat deposition

EFED, Efficiency of fetal development;

EFM, Efficiency of adult fat mobilization ;

EL, Efficiency of milk production from dietary energy ;

ELT, Efficiency of milk production from tissue energy;

EPD, Efficiency of adult protein deposition;

EPLD, Efficiency of placental development ;

EPM, Efficiency of adult protein mobilization ;

FEC, Food energy content (kcal/gm) ;

FMX, Max. energy available for gestation from adult energy stores (kcal/day) ;

FMXL, Maximum energy available for lactation adult energy stores (kcal/day) ;

GFJ, Gross food intake (gm/day);

PCL, Protein control level (gm);

TPRQ, Total protein energy requirement (kcal) ;

TREA, Adult thermoregulation requirement (kcal). 
it to normal. In addition to the deposition or mobilization of energy, energy equilibrium may also be maintained through reductions in maintenance or reproductive energy expenditures. Gross food intake, ambient temperature, and litter size are input to the model, with the outputs being adult body weight, adult body composition, juvenile body weight, and juvenile body composition through time. Figure 1 is a Forrester diagram for the model. A detailed description of the model is given in Heasley (1977).

Following the first lab experiment the model was run and compared with selected data sets and erroneous hypotheses were recognized and rejected. Alternative hypotheses were implemented and the model was rerun to check for consistency of variables with respect to observed values. At this time any obvious gaps in data or knowledge were identified and experimental procedures modified to correct these deficiences. Following the second lab experiment the model was once more run with selected data sets and its ouput compared with observed data. Further refinements were made in parameters and structure. A thorough verification of the model was performed after these final refinements were made. That is,

Tabela 1

Estimated adult body weight errors for given errors in food intake, activity expenditures, and juvenile energy demand for a lactating mouse weighing 33 grams.

\begin{tabular}{lccc}
\hline \multicolumn{1}{c}{ Variable } & $\begin{array}{c}\text { Relative } \\
\text { magnitude } \\
\text { of errors }\end{array}$ & $\begin{array}{c}\text { Actual } \\
\text { magnitude of } \\
\text { body weight } \\
\text { errors }\end{array}$ & $\begin{array}{c}\text { Propagated } \\
\text { errors }\end{array}$ \\
\hline Body weight & 101 & $0.77 \mathrm{gm}$ & $0.77 \mathrm{gm}$ \\
$\begin{array}{l}\text { Food intake } \\
\text { Activity }\end{array}$ & $10 \%$ & $0.09 \mathrm{gm} / \mathrm{day}$ & $1.76 \mathrm{gm}$ \\
Juvenile demand & $10 \%$ & $0.10 \mathrm{gm} / \mathrm{day}$ & $1.00 \mathrm{gm}$ \\
Total error & $10 \%$ & $0.16 \mathrm{gm} / \mathrm{day}$ & $1.60 \mathrm{gm}$ \\
\% Body weight error for a $33 \mathrm{gm}$ mouse $=15.55 \%$ & $5.13 \mathrm{gm}$ \\
\hline
\end{tabular}

1 One standard deviation.

equations were checked for completeness and to see that they were dimensionally correct. Extremes were simulated (e.g., zero intake and low temperature) and the output checked for consistency with observed values. The model was then validated against observed data to test the hypothesis it represented. A test criterion requiring that the model predict individual body weights within $\pm 15 \%$ of those observed was derived through the analysis of critical measurement errors (food intake, activity, juvenile energy demand). Estimates of these errors are given in Table 1.

\section{RESULTS}

Mean assimilation efficiency was $0.73 \pm 0.007$ (all mean values are given as the mean \pm one standard error). This is consistent with data (0.69-0.73) collected by Smith \& McManus (1975). Mean food energy content was $4.172 \pm 0.0465 \mathrm{kcal}$, compared with $4.25 \mathrm{kcal}$ given by a Purina Lab Chow analysis.

The general weight patterns exhibited by pregnant and lactating mice 
were very similar to those found in the literature (Myrcha et al., 1969). Body weight is generally constant during gestation up to day 12 , followed by an exponential rise through parturition. During lactation, many females maintained a constant body weight. Some of these maintained body weight within \pm 0.5 grams for several consecutive days. Food intake increased slightly through the fifteenth day of gestation. This was followed by a generally linear increase in intake through lactation until the young were weaned. With many of the mice, intake was quite erratic, resulting in fluctuations in female body weight. There appears to be considerable mobilization of fat stores during lactation. The fat content of females sacrificed at the beginning of lactation (2.16 $\pm 0.365 \mathrm{gram} s)$ was significantly greater $(p \leqslant 0.01)$ than that of those at the end $(0.81 \pm 0.63$ grams). Eight-six percent of all females fed ad

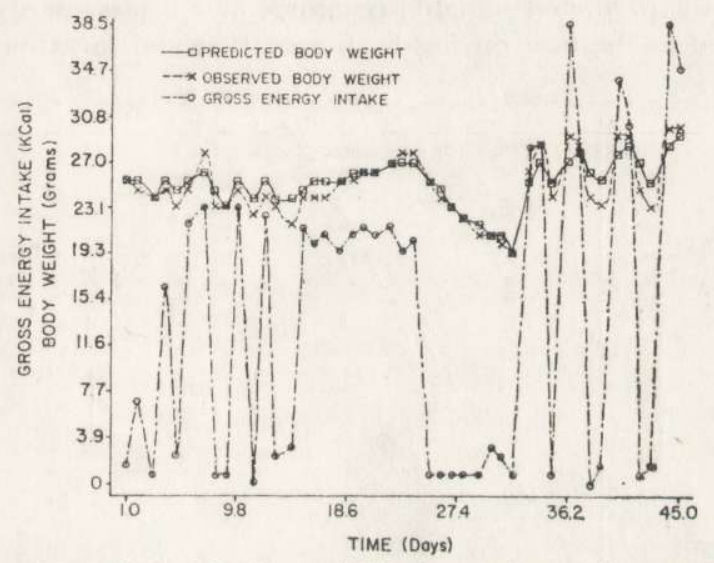

Fig. 2. Observed and predicted body weight dynamics and gross energy intake for a nonpregnant female mouse (Mouse No. 52).

libitum had less than one gram of fat at the end of lactation. Figures 2,3 , and 4 depict examples of body weight and gross energy intake for nonpregnant females, pregnant females, and juveniles. Body weight predicted from the energy allocation model simulation is also shown in comparison.

Decreased intake at various times during gestation and lactation resulted in female weight loss $(1.37 \pm 0.151$ grams/day) and lower birth weights $(0.12 \pm 0.002$ grams lower than expected weights). Lower milk production, manifested in a reduction in juvenile growth rates $(0.17 \pm$ 0.046 grams/day) and sometimes in juvenile weight loss $(0.24 \pm 0.031)$, and an increased number of juveniles consumed also occurred in response to reduced food intake. From a comparison of model predictions with observed weight loss in stressed individuals, there appears to be a reduction in basal metabolism (as predicted by the body weight equation; 


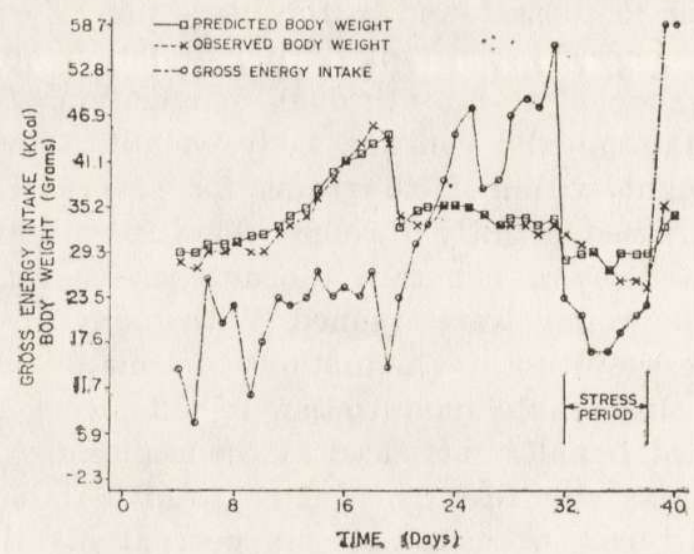

Fig. 3. Observed and predicted weight dynamics and gross energy intake a female fed ad libitum during both gestation and lactation.

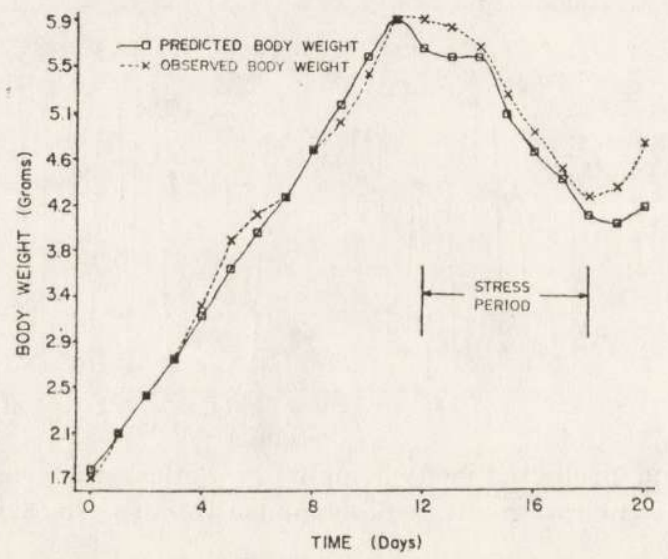

Fig. 4. Mean observed and predicted body weight dynamics for juveniles of a litter nursed by a female fed ad libitum.

Brody, 1945), activity expenditure, and lactation in response to decreased intake. To account for this phenomenon, reduction mechanisms were incorporated into the model (Heasley, 1977). When stressed individuals were returned to ad libitum levels, female body weight returned to pre-stress levels sooner than juvenile body weight. Lactation and juvenile body weight appeared to lag behind the replenishment of female energy stores. Within one day, however, juvenile growth rates returned to normal and in some cases exhibited compensatory reactions. This was also observed by Wilson \& Osbourn (1960). Figures 5 and 6 show an example of the responses of observed female and juvenile body weights to energy stress and of predicted body weight and gross energy intake. 


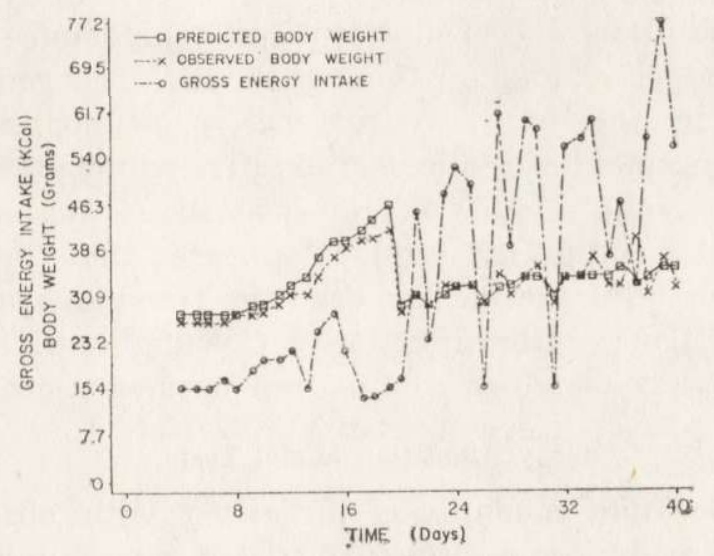

Fig. 5. Observed and predicted body weight dynamics and gross energy intake for a female fed $40 \%$ ad libitum from the twelfth through the eighteenth day of lactation. Ad libitum levels were maintained during the remainder of the reproductive cycle.

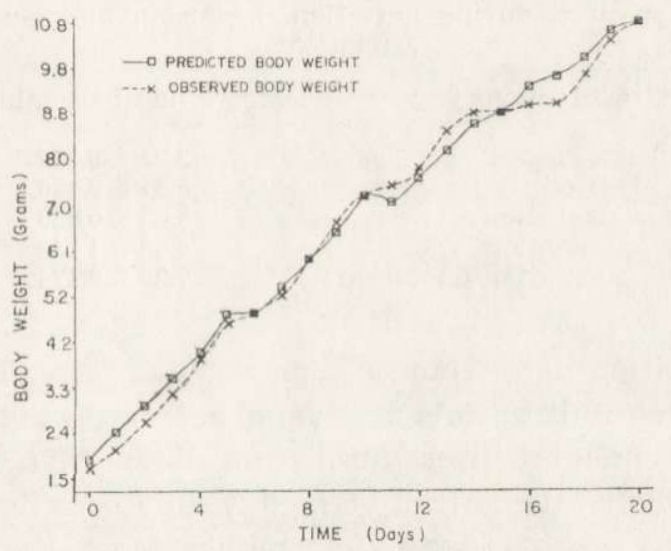

Fig. 6. Mean observed and predicted body weight dynamics for a litter nursed by a female fed $40 \%$ ad libitum from the twelfth through the eighteenth day lactation. Ad libitum levels wert maintained during the remainder of the reproductive cycle.

There is a definite increase in the incidence of cannibalism as a result of energy stress (see Table 2). The difference in the number of young eaten between nonstressed and stressed individuals is significant at the one-percent level $(p \leqslant 0.01)$. There is, however, no significant difference in the occurrence of cannibalism between nonstressed individuals and those stressed during gestation only. Individuals returned to normal intake levels at parturition did not exhibit an increase in cannibalistic behavior over nonstressed individuals. Of the 15 mice stressed during 
gestation and lactation, six consumed their entire litters by the first day of lactation. In addition, six of the remaining nine mice had reduced their litters to one individual by the eighth day. The general response to stress during lactation was an occurrence of cannibalism within one day of the commencement of reduced intake. The number eaten, however, was not as great as the number eaten when stress was applied during both gestation and lactation $(p \leqslant 0.10)$. It appeared that the cannibalistic behavior continued until the energy drain of lactation was sufficiently relieved. That is, females continued to eat young until a given litter size was reached, beyond which cannibalism no longer occurred.

\section{Energy Allocation Model Tests}

The energy allocation model was initialized with observed female body weight and body composition calculated as a function of body weight. This calculation was based on a regression analysis performed

Table 2

Mean number of young eaten for nonstressed females and females stressed during gestation, lactation, and gestation/ /lactation.

\begin{tabular}{cc}
\hline Energy stress category & Mean number eaten $\pm \mathrm{SE}$ \\
\hline Nonstressed & $2.31 \pm 0.382$ \\
Stressed & $5.31 \pm 0.490$ \\
Gestation & $3.00 \pm 0.830$ \\
Lactation & $4.63 \pm 1.149$ \\
Gestation/Lactation & $7.29 \pm 0.474$ \\
\hline
\end{tabular}

with body composition data from 46 nonpregnant mice. These were mice sacrificed during feasibility trials conducted before the actual experiments to establish experimental procedures and develop techniques. Adult protein control levels (genetically fixed protein content of an adult mouse of a given weight) were determined from the observed body composition for each individual mouse used in the model tests. Utilizing initial body weight and protein control level data as independent variables, initial fat content was calculated from the derived regression equation with an $R^{2}$ of 0.71 . The model was driven with food intake, temperature, and litter size data recorded for each individual mouse. Eighty-six model tests of body weight prediction were conducted. Of these, 18 were for nonpregnant and 68 were for pregnant individuals. Fifty-three litters were simulated through lactation and the model output tested against observed juvenile body weight. The predicted body weight met the test criterion for $100 \%$ of the adults and $91 \%$ of the juveniles. Failure to meet the test criterion for juveniles usually occurred during the first few days of lactation, when the absolute allowable error in 
predicted weight is very small. If you omit the first three days of the lactation period, the test criterion would be met for $97 \%$ of the juveniles. Table 3 gives a summary of the magnitude of prediction errors exhibited by the energy allocation model. Adult lean dry content errors are not given, as they were very small due to the use of observed protein levels

Table 3

Summary of energy allocation model prediction errors for adult and juvenile body weight and composition.

\begin{tabular}{lcc}
\hline \multicolumn{1}{c}{ Item } & $\begin{array}{c}\text { Mean observed } \\
\text { value (grams) }\end{array}$ & $\begin{array}{c}\text { Mean error } \pm \text { SE } \\
\text { (grams) }\end{array}$ \\
\hline Adult body weight & 33.13 & $1.62 \pm 0.078$ \\
Juvenile body weight & 8.86 & $0.35 \pm 0.025$ \\
Adult fat content & 1.71 & $1.31 \pm 0.123^{1}$ \\
Juvenile fat content & 0.73 & $0.29 \pm 0.042^{1}$ \\
Juvenile lean dry content & 1.83 & $0.23 \pm 0.026^{1}$ \\
\hline
\end{tabular}

${ }^{1}$ Body composition errors are cumulative, as they are measured at the end of the experiment. Therefore, they may be much higher than the average over the run.

to determine protein control levels. For a detailed summary of the model results for each individual mouse, see Heasley (1977).

\section{DISCUSSION}

The results of this study indicate that energy allocation in mice appears to adhere to the principles dictated by the law of conservation of energy. The data show that energy equilibrium is maintained through increased intake, mobilization of energy stores, and the reduction of energy expenditures. The phenomena observed support the observations of others with respect to the character of energetic relationships and the qualitative effects of energetic imbalance. Mice, as do voles (Migula, 1969; Kaczmarski, 1966) and rats (Randolph et al., 1977), increase food intake during pregnancy, with the greatest increase occurring during the last three days. Lactation represents a very heavy energetic cost to the organism, as indicated by the large increase in intake. In this study, those mice with large litters $(>8)$ consumed as much as $300 \%$ more than nonpregnant mice at the peak of lactation. Those with small litters $(<4)$ consumed only twice as much as nonpregnant mice. Although mice have the ability to compensate for increased energy demand through increased intake, apparently the compensation is not perfect. There is a linear relationship between average juvenile growth rate and litter size. Juveniles from large litters grow at a slower rate and are weaned at a lower body weight than those from small litters. The effect of 
litter size probably acts through competition among juveniles for milk from the female, thus permitting less suckling time per individual, and through the physiological milk production rate limitations of the species.

In attempting to elucidate the mechanisms of energy allocation in small mammals, I found that many of these mechanisms were not directly observable in the empirical sense. Questions concerning what limits the amount of energy expended for reproductive functions during periods of reduced intake and what adjustments in maintenance expenditures, if any, occur during those periods were explored through model experiments. Simulation modeling allows you to examine hypotheses regarding specific mechanisms by mathematically formulating these hypotheses in a model and comparing model predictions with observed data (body weight and composition). These experiments, in turn, suggest hypotheses for future experiments and have been formulated into a conceptual (second-generation energy allocation model that has not been implemented) model for energy allocation. Discussion of specific results will be in conjunction with this conceptual model.

\section{Conceptual Model for Energy Allocation}

The maintenance of energy equilibrium is accomplished through the control of various biochemical reactions that may be input controlled or rate limited by the presence or absence of catalytic substances. An input-controlled system is one in which the output is limited by the magnitude of the input; e.g., internal combustion engine output is limited by the size of the gasoline charge. The metabolic rate of the cells may be dependent upon the energy state of the cell (ATP levels) or the levels of various enzymes in the cell (Black \& Bruss, 1974). Under absorptive conditions the metabolic rate of the cell becomes enzyme limited, thus necessitating the conversion of excess input energy to a storage form. As the post-absorptive state is reached, metabolic rate is both enzyme and input controlled. That is, it is enzyme controlled as long as the maximum rate of mobilization of energy stores (potential input energy) is greater than the input energy dictated by enzyme levels. Metabolic rate becomes input controlled when the magnitude of potential input energy falls below the maximum level allowed by the enzymes present in the cell. There is evidence to suggest that the rate of fat catabolism is related to the level of fat stores (Bray \& Campfield, 1975). As fat stores become depleted, metabolic rate would shift hypothetically to input control and be limited by the rate of fat catabolism. As the metabolic rate of the cells approaches the minimum or lethal level, greater amounts of protein are catabolized to supplement the reduced supply of fatty acids. Eventually, irreversible damage occurs and death from starvation ensues. 
When fat levels are normal, the rate at which they may be mobilized is probably much greater than the normal metabolic rate set by cell enzymes. This is borne out by the fact that under temperature stress, metabolism rises to rates many times greater than basal levels (Alexander, 1962a). Under these conditions, the increased heat production may be brought about through neural stimulation of enzyme activity, thus increasing cell metabolic rate, allowing fat catabolism to proceed maximally. The data of Alexander (1962b) seem to indicate a reduction in maximum metabolic rate with exposure time, perhaps reflecting the decrease in fat stores. An assumption that the maximum rate of fat catabolism is related to fat levels would account for the death of fasting animals under cold conditions even though ample fat reserves remained. Kleiber (1961) found that starved rats kept at low temperatures exhibited a reduction in metabolic rate with time and died sooner, possessing higher fat levels than those starved at higher temperatures.

Gestation represents an additional energy demand normally met through increased energy intake. It is believed by many that the fetus derives its energy primarily from glucose (Graham, 1968). During starvation, glucose utilization is curtailed. Tsoulos et al. (1971) found that glucose metabolism accounted for only $20 \%$ of the $\mathrm{O}_{2}$ uptake in starved pregnant ewes. Glucose transport to placental membranes was reduced to $36 \%$ of that under ad libitum conditions. Ewes may become hypoglycemic under energy stress conditions (Reid, 1963). Fetal development is therefore most likely limited by maximum rate of glucenogenesis during reduced energy intake.

Lactation places a significant energy demand on the female, especially one with a large litter. This energy demand may be met through increased intake, but in many cases must be supplemented from mobilized energy stores. During energy stress, the production of milk energy may be limited through the reduction in lactose or protein synthesis. Lactose plays a major role in the control of milk secretion through its contribution to the osmotic pressure (thus water movement) of milk (Schmidt, 1971). The primary precursor of lactose is blood glucose. Under postabsorptive conditions, blood glucose is limited by the rate of gluconeogenesis. Protein synthesized by the mammary glands is derived from blood amino acids. As with glucose levels, amino acid levels are dependent upon their release into the blood from functional proteins. Therefore, the amount of energy available through lactation during energy stress is probably limited by the maximum rate of gluconeogenesis or release of amino acids from tissue proteins. A Forrester diagram for this conceptual model is given in Figure 7. Some of the ideas presented in the model do not have substantial direct empirical support. However, it is 
hoped that they may stimulate new ideas, or the integration of discrete ideas, and future research dealing with the mechanisms involved in the maintenance of energy equilibrium.

In the course of model experiments with data collected from intermittently starved mice, it was determined that overall metabolic rate decreased with starvation time. This reduction in metabolic rate was made a function of the ratio of net energy intake to total energy expenditures. From the conceptual model previously described, this reduction might be explained as the result of a reduction in energy supply in an input-controlled system. That is, as fat stores are decreased,

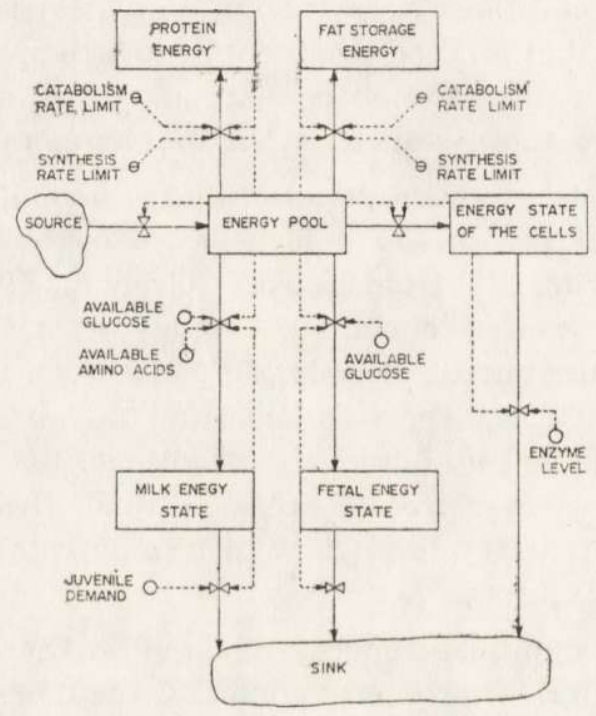

Fig. 7. A Forrester diagram of a conceptual model for energy allocation in small mammals, based on the results of this study.

the rate of fat catabolism also decreases. Eventually, this reduction brings about a shift to input control, thus causing metabolic rate to fall with it. When energy is again taken in, control shifts to enzyme limitation and metabolic rate returns to normal levels. The ratio of net energy intake to total energy expenditures is an index of the ene:getic state of the organism. Low values of this ratio are indicative of conditions under which input control might be realized. The form of the reduction mechanisms (exponential decay) used in the energy allocation model is consistent with the amount of energy available from fat stores (as a function of time) when the maximum rate of fat catabolism is assumed to be linearly related to fat levels. 
The Role of Cannibalism in Energy Allocation

Cannibalism has been observed in many species under both laboratory and field conditions. The degree of cannibalism may vary with food availability, population density, the behavior of both the cannibal and the victim, social stress, and the availability of victims (Fox, 1975). Starvation may increase cannibalistic tendencies but is not essential for cannibalism to occur. Cannibalism may be simply a response to a reduction in the relative availability of food alternatives. (Some insects may consume their young simply because they are much more available than other food sources). Mice have been shown to exhibit cannibalism under crowded conditions, even when supplied with excess food and nesting material (Southwick, 1955).

In this study, the incidence of cannibalism increased under conditions of reduced energy intake. Energy stress during gestation had little effect on the occurrence of cannibalism during lactation. Rodents normally put on fat during gestation (Randolph et al., 1977). Energy stress probably reduces this fat deposition. As long as adequate food intake is maintained during lactation, the incidence of cannibalism should not be significantly different from that observed under normal conditions. Continuing energy stress into lactation or applying energy stress during lactation had a significant effect $(P \leqslant 0.05)$ on the occurrence of cannibalism. The physiological trigger for this behavior is unknown. It may be related to the energy state of the animal, the rate of mobilization of energy stores, and/or protein requirements during lactation. At any rate, it poses an interesting question for future research. Cannibalism is an energetically advantageous strategy for the maintenance of energy equilibrium in organisms with high reproductive rates. It not only increases energy intake but also reduces the energy expenditures of lactation, thus increasing the probability of survival through the energy stress period into a more favorable period for reproduction.

\section{REFERENCES}

1. Alexander G., 1962a: Temperature regulation in the newborn lamb. Aust. J. Agric. Res., 13: 100-121.

2. Alexander G., 1962b: Energy metabolism in the starved newborn lamb. Aust. J. Agric. Res., 13 : 144-164.

3. Baile C. A. \& Forbes T. M., 1974: Control of feed intake and regulation of erergy balance in ruminants. Physiol. Rev., 54: 160-214

4. Bırnes R. H., Kwong E., Morrisey L., Vilhjalmsdottir L. \& Levitsky D., 1973 : Maternal protein deprivation during pregnancy or lactation in rats and the efficiency of food and nitrogen utilization of the progeny. J. Nutr., 10: 273284.

5. Back A.L. \& Bruss M. L., 1974: Present concept and future directions of rearch on the control of metabolism. [In: "The control of metabolism", 
J. D. Sink, ed.]. The Pennsylvania State Univ. Press: 225-252. University Park.

6. Bray G. A. \& Campfield L. A., 1975: Metabolic factors in the control of energy stores. Metab. Clin. Exp., 24: 99-117.

7. Corah L. R., Dunn T.E. \& Kaltenbach C. C., 1975: Influence of prepartum nutrition on the reproductive performance of beef females and the performance of their progeny. J. Anim. Sci., 41: 819-824.

8. Forrester J.W., 1961: Industrial dynamics. M.I.T. Press : 1-464. Cambridge.

9. Fox L.R., 1975: Cannibalism in natural populations. Annual Rev. Ecol. Syst., $6: 87-106$.

10. Graham N. McC., 1968: Effects of undernutrition in late pregnancy on the nitrogen and energy metabolism of ewes. Aust. J. Agric. Res., 19: 555-565.

11. Green E. L., 1966: Biology of the laboratory mouse. McGraw-Hill: 1-706. New York.

12. Heasley J. E., 1977: Energy allocation in small mammals and its influence on their population dynamics: A laboratory and simulation study. Ph.D. Dissertation. Utah State University.

13. Kaczmarski F., 1966: Bioenergetics of pregnancy and lactation in the bank vole. Acta theriol., 19: 409-417.

14. Kleiber M., 1961: The fire of life. John Wiley \& Sons : 1-454. New York.

15. Laird A. K., 1966: Dynamics of embryonic growth. Growth, 30: 273-275.

16. Lodge G. A. \& Heaney D. I., 1973 : Composition of weight change in the pregnant ewe. Can. J. Anim. Sci., 53: 95-105.

17. Migula P., 1969: Bioenergetics of pregnancy and lactation in the European common vole, Microtus arvalis (Pallas, 1779). Acta theriol., 14: 167-179.

18. Moose M. G., Ross C. V. \& Pfander W. H., 1969: Nutritional and environmental relationships with lambs. J. Anim. Sci., 29: 619-627.

19. Myrcha A. L., Ryszkowski L. \& Walkowa W., 1969 : Bioenergetics of pregnancy and lactation in the white mouse. Acta theriol., 14:161-166.

20. Peterson A.D. \& Baumgardt B. R., 1971: Food and energy intake of rats fed diets varying in energy concentration and density. J. Nutr., 101: 1057-1068.

21. Randolph P. A., Randolph J.C., Mattingly K. \& Foster M. M., 1977: Energy costs of reproduction in the cotton rat, Sigmodon hispidus. Ecology, 58: 3145.

22. Reid R. L., 1963 : The nutritional physiology of the pregnant ewe. J. Aust. Inst. Agric. Sci., 29 : 215-223.

23. Schmidt G. H., 1971 : Biology of lactation. W. H. Freeman \& Co. : 1-317. San Francisco.

24. Sinclair A. J. \& Crawford M. A., 1973: The effect of a low-fat maternal diet on neonatal rats. Br. J. Nutr., 29: 127-137.

25. Smith B.W. \& McManus J. J., 1975: The effects of litter size on the bioenergetics and water requirements of lactating Mus musculus. Comp. Bioch. Physiol. A., 51: 111-115.

26. Southwick C. H., 1955: Regulatory mechanisms of house mouse populations: Social behavior affecting litter survival. Ecology, $36: 627-634$.

27. Tsoulos N. G., Colwill J. R., Battaglia F.C., Makowski E. L. \& Meschia G., 1971: Comparison of glucose, fructose, and $\mathrm{O}_{2}$ uptakes by fetuses of fed and starved ewes. Am. J. Physiol., 221 : $234-237$. 
28. Wilson P. M. \& Osborn D. F., 1960 : Compensatory growth after under-nutrition in mammals and birds. Biol. Rev., $35: 324-363$.

Accepted, May 10, 1982.

\section{John E. HEASLEY}

\section{WYKORZYSTANIE ENERGII PRZY ZNIŻONYM POBRANIU POKARMU U CIĘZARNYCH I KARMIĄCYCH MYSZY LABORATORYJNYCH}

Streszczenie

Badania nad mechanizmem wykorzystania energii $u$ małych ssaków robiono w oparciu o doświadczenia i próby modelowe (Ryc. 1). W celu otrzymania danych o zależnościach między ciężarem i składem ciała, produkcją mleka i pobraniem pokarmu u Mus musculus, przeprowadzono dwa rodzaje doświadczeń z karmieniem myszy. W pierwszym - 40 ciężarnych samic umieszczonych w pojedynczych klatkach metabolicznych, dostawało pokarm i wodę ad libitum. Określano dobowe pobranie pokarmu, oraz codziennie ważono myszy i ich mioty a także notowano wielkość miotu i przypadki kanibalizmu. Drugie doświadczenie polegało na podzieleniu 60 ciężarnych samic na 4 grupy, z których: pierwsza miała pokarm podawany ad libitum, drugiej ilość pokarmu zmniejszono tylko w czasie ciąży, trzeciej - w czasie ciąży i laktacji i czwartej - tylko w czasie laktacji. Samice, które nie zaszły w ciążę traktowano jako kontrolę (Tabela 1, Ryc. 2-3).

Symulacyjny model wykorzystania energii u małych ssaków rozwinięto w oparciu o dane i koncepcje literaturowe a model doświadczalny w oparciu o dane z przebiegu procesu pokarmowego. Przewidywane zmiany ciężaru ciała porównano z wynikami, celem sprawdzenia hipotezy o wykorzystaniu energii na poszczególne procesy (Ryc. 4 -6). Zaniżone pobranie powoduje utratę ciężaru ciała samic, niższy ciężar noworodków, zmniejszenie produkcji mleka oraz wzrost kanibalizmu (Tabela 2). Obniżeniu uległ także metabolizm podstawowy i aktywność. Spodziewane zmiany ciężaru ciała zachodziły u wszystkich z 86 badanych myszy i $91 \%$ z 53 uzyskanych miotów. Energia zużywana na ciążę i laktację okazuje się być stała i zapewne limituje ją maksymalne tempo glukoneogenezy. Zniżenie wydatków energetycznych przy obniżonym dostępie pożywienia można wyjaśnić mniejszą ilością kwasów tłuszczowych, po wyczerpaniu zapasów tłuszczu (Ryc. 7). 